\title{
Residency Training: The Review Committee for Neurology
}

\section{Revisions to the Common Program Requirements}

Kathryn S. Nevel, MD, Andrew M. Southerland, MD, MSc, Shannon M. Kilgore, MD, and Laurie Gutmann, MD

Neurology ${ }^{\oplus}$ 2018;90:41-44. doi:10.1212/WNL.0000000000004766

As part of a scheduled review of the Common Program Requirements, the Accreditation Council for Graduate Medical Education (ACGME) recently implemented amendments to Section VI, "Resident Duty Hours in the Learning and Working Environment," which went into effect on July 1 , 2017. ${ }^{1}$ Prior to July 1 , changes to Section VI of the Common Program Requirements were last implemented by the ACGME in 2011. The purpose of this review is to discuss the recent changes to Section VI of the ACGME Common Program Requirements.

\section{Accreditation Council for Graduate Medical Education}

The ACGME accredits residency and fellowship programs and sponsoring institutions, with dedicated resources to addressing aspects of the clinical learning environment. While the ACGME spearheads many initiatives to enhance the clinical learning environment, the ACGME's principal mission is to improve health care and population health by assessing and advancing the quality of resident physician education through accreditation. ${ }^{2}$ The ACGME oversees 29 Review Committees; each Review Committee accredits all training programs within its respective specialty.

\section{Review Committee for Neurology}

The Review Committee for Neurology comprises 13 members: 3 organizations each nominate 3 members: the American Board of Psychiatry and Neurology, the American Academy of Neurology (AAN), and the American Medical Association; the Child Neurology Society nominates 1 member; and 1 member represents the American Osteopathic Association. A public member and a resident member are selected by the Committee through an application process. The resident member serves on the Committee for 2 years; the other members serve 6 years each.

The Review Committee for Neurology serves to accredit adult and child neurology residency programs, as well as fellowship programs in 9 subspecialties. Programs are accredited through review of annual Resident and Faculty Survey results, board pass rates, educational curriculum, faculty and resident scholarly activity, and site visit information. The Common Program Requirements, defined by the ACGME, cover a broad range of topics in the clinical learning environment regardless of specialty and include requirements for institutional and program resources, resident appointments, evaluations, patient safety, work hour limits, professionalism, transitions of care, and supervision. ${ }^{3}$ Educational curriculum and clinical requirements are determined by each specialty Review Committee; the Review Committee for Neurology completes neurology-specific requirements.

\section{Duty hour regulations}

Resident duty hour regulations attempt to balance 2 competing aims: the safety of residents' current patients and that of their future patients through residents' attainment of medical knowledge and skills. ${ }^{4}$ Ensuring this delicate balance is challenging and requires ongoing assessment of both patient and physician outcomes.
Correspondence

Dr. Nevel

nevelk@mskcc.org

From Neuro-Oncology (K.S.N.), Memorial Sloan Kettering Cancer Center, New York, NY; Department of Neurology (A.M.S.), University of Virginia Health System, Charlottesville; Department of Neurology (S.M.K.), Stanford University, CA; and Department of Neurology (L.G.), University of lowa, lowa City.

Go to Neurology.org/N for full disclosures. Funding information and disclosures deemed relevant by the authors, if any, are provided at the end of the article. 
In 2003, the ACGME adopted the following duty hour regulations into the Common Program Requirements: a maximum 80-hour work week, 1 day off in 7 averaged over 4 weeks, and maximum 24 hours of scheduled continuous duty with up to 6 additional hours allowed. In 2009, the ACGME commissioned a task force to review the duty hour standards implemented in 2003. Due to testimony and literature indicating interns worked longer hours than senior residents, and that more errors occurred from fatigue, the ACGME added more requirements in 2011. ${ }^{5}$ These requirements include that interns cannot exceed 16 hours of continuous work, upper level residents cannot exceed 24 hours of continuous work plus an additional 4 hours allowed for specific circumstances, residents must have 14 hours off between 24-hour shifts and 8 hours off between other shifts, and night duty is limited to 6 consecutive nights. ${ }^{5}$

Though the 2011 standards were adopted, the medical community debated their benefit to patient care, resident education, and resident well-being. In January 2016, the AAN, along with more than 60 other member organizations, submitted a position statement to the ACGME describing unintended consequences of the current duty hour restrictions. ${ }^{6}$ Though intern work hours are not typically directed by neurology programs, the AAN expressed concern that limiting intern work hours left residents unprepared for the longer hours and greater patient responsibilities of PGY-2 years. Other unintended consequences of the current duty hour regulations include decreased continuity of care, increase in patient handoffs, and increase in shift work mentality. ${ }^{6}$

The only prospective study on duty hour regulations among neurology residency programs evaluated residents on measures of burnout, sleepiness, and satisfaction with patient care and education, as well as faculty satisfaction with resident patient care and knowledge. The study used a control month using the 2003 ACGME duty hour requirements, and an intervention month using more restrictive requirements limiting the number of continuous hours worked. ${ }^{7}$ During the intervention month, residents reported lower scores in quality of life, patient care, and satisfaction with education, while faculty reported lower scores on resident knowledge and quality of care. There was no improvement in resident sleepiness or increase of sleep time during the intervention month, despite the shorter shift length. Though small, this study suggested more restrictive work hours during training may adversely affect neurology resident education and patient care.

In more recent years, 2 additional prospective trials have evaluated the effect of longer continuous work hours on resident and patient outcomes. The Flexibility in Duty Hour Requirements for Surgical Trainees (FIRST) trial is a national randomized trial among general surgery residents comparing the 2011 duty hour regulations to a more flexible schedule, allowing residents to work longer continuous hours. ${ }^{8}$ Results from the 2014 to 2015 years revealed non-inferiority in the flexible group on almost all patient outcome measures; residents in the flexible group were less dissatisfied on metrics of perceived quality of patient care and trainee education, but more dissatisfied on some individual measures of personal well-being. The trial was extended to the 2016-2017 years, with results pending. A similar trial, Individualized Comparative Effectiveness of Models Optimizing Patient Safety and Resident Education (iCOMPARE), among internal medicine programs completed participation in July 2016, with results pending. ${ }^{9}$ Characteristics and outcomes of these 3 prospective duty hour studies are summarized in table 1.

\section{Section VI of the Common Program Requirements: Changes}

In late 2015, the ACGME scheduled a revision of the entire Common Program Requirements. A task force comprising members of the ACGME Board of Directors, along with Chairs and resident members of various Review Committees, was formed to revise Section VI of the Common Program Requirements: "Resident Duty Hours in the Learning and Working Environment.” Revision of Sections I-V is still in process. This task force reviewed scientific literature, position statements from medical member organizations, comments from the public sector, and testimony at the ACGME Congress in March 2016 before rewriting Section VI. Proposed modifications were published on November 4, 2016, followed by a 45-day public comment period. The task force reviewed all comments before submitting a revised Section VI to the ACGME Board of Directors. The Board approved the finalized version, which was announced at the ACGME Educational Conference on March 10, 2017, and were implemented across all ACGME-accredited training programs on July 1, 2017. Though many changes were made to Section VI, work hour regulation modifications will serve as the most visible difference in residency training.

Duty hours, renamed "Clinical Experience and Education" in Section VI, includes several notable modifications, listed in table 2. ${ }^{3}$ The new regulations extend continuous hours worked for interns to 24 hours, and allow trainees to continue working beyond the maximum 24 continuous hours scheduled, if on their own initiative. Clinical work conducted from home must now be counted toward the unchanged maximum 80-hour work week. Additional changes detail aspects of a supportive and effective clinical learning environment, and include modifications to address patient safety, quality improvement, supervision, and accountability, and add requirements to support physician well-being. ${ }^{3}$

By allowing flexibility within programs to create schedules that best support their clinical learning environment, it is anticipated that patient safety and trainee education will be enhanced. ${ }^{3}$ Extending interns' continuous work hours will allow interns to function as equal partners on the team, improving continuity of care as well as education. It will also minimize delay in resident maturation during intern year, particularly important to neurology programs, since PGY-2 residents are often on the frontlines in their new specialty. As neurology residents continue clinical work from home in the form of 
Table 1 Characteristics and outcomes of highlighted duty hour studies

\begin{tabular}{|c|c|c|c|}
\hline Study & Description & Trainee outcomes & Other outcomes \\
\hline \multicolumn{4}{|l|}{ FIRST $^{a}$} \\
\hline Participants & $\begin{array}{l}\text { PGY-1-PGY-5 Surgery residents } \\
\text { (4,330 residents from } 117 \\
\text { programs) }\end{array}$ & $\begin{array}{l}\text { Primary: No significant } \\
\text { difference in resident } \\
\text { dissatisfaction with overall } \\
\text { education or well-being }\end{array}$ & $\begin{array}{l}\text { Primary: Noninferiority of } \\
\text { flexible group for death and } \\
\text { serious complications }\end{array}$ \\
\hline Study design & $\begin{array}{l}\text { Programs randomized to } \\
\text { "standard-policy" group ( } 2011 \\
\text { requirements) vs "flexible-policy" } \\
\text { group (intervention) }\end{array}$ & $\begin{array}{l}\text { Secondary: Flexible group less } \\
\text { likely to perceive a negative } \\
\text { effect of duty hours on patient } \\
\text { care; flexible group more } \\
\text { likely to perceive negative } \\
\text { effect on various measures of } \\
\text { personal well-being }\end{array}$ & $\begin{array}{l}\text { Secondary: Noninferiority of } \\
\text { flexible group for any } \\
\text { complication, unplanned } \\
\text { reoperation, or infection; } \\
\text { inconclusive for unadjusted } \\
\text { 30-day mortality, though } \\
\text { flexible group noninferior in } \\
\text { the adjusted analysis }\end{array}$ \\
\hline
\end{tabular}

\begin{tabular}{lll}
\hline Intervention & $\begin{array}{l}\text { PGY-1 residents can work }>16 \\
\text { hours; PGY-2-PGY-5 residents can } \\
\text { work }>24 \text { hours; no amount of } \\
\text { required time off between shifts } \\
\text { for any PGY level }\end{array}$ \\
\hline iCOMPARE & & \\
\hline Participants & $\begin{array}{l}\text { PGY-1-PGY-3 Internal medicine } \\
\text { residents (63 internal medicine } \\
\text { residency programs) }\end{array}$ & $\begin{array}{l}\text { Ongoing, results not } \\
\text { published; assessing trainee } \\
\text { sleep duration, behavioral } \\
\text { alertness, self-perceived } \\
\text { sleepiness, time spent in } \\
\text { direct patient care, trainee } \\
\text { satisfaction with education }\end{array}$
\end{tabular}

\begin{tabular}{|c|c|c|c|}
\hline Study design & $\begin{array}{l}\text { Programs randomized to } \\
\text { "standard-policy" group ( } 2011 \\
\text { requirements) vs "flexible-policy" } \\
\text { group (intervention) }\end{array}$ & & \\
\hline Intervention & $\begin{array}{l}\text { Flexible schedules determined by } \\
\text { programs, but must comply with } \\
80 \text {-hour work week, call no more } \\
\text { than every } 3 \text { days, } 1 \text { day off in } 7 \text { (all } \\
\text { averaged over } 4 \text { weeks) }\end{array}$ & & \\
\hline \multicolumn{4}{|l|}{ Neuro IOM $^{\mathrm{c}}$} \\
\hline Participants & $\begin{array}{l}\text { PGY-2-PGY-4 Neurology residents } \\
\text { (34 residents from } 3 \text { residency } \\
\text { programs) }\end{array}$ & $\begin{array}{l}\text { Residents reported greater } \\
\text { dissatisfaction with quality of } \\
\text { life at work, knowledge of } \\
\text { patients, and continuity of } \\
\text { care, and increased burnout } \\
\text { during the flexible month; no } \\
\text { difference between control } \\
\text { and intervention months on } \\
\text { measures of time spent on } \\
\text { educational activities or sleep }\end{array}$ & $\begin{array}{l}\text { Attending physicians more } \\
\text { dissatisfied with residents' } \\
\text { knowledge and quality and } \\
\text { continuity of care of patients, } \\
\text { as well as preparedness for } \\
\text { rounds }\end{array}$ \\
\hline
\end{tabular}

\begin{tabular}{|c|c|}
\hline Study design & $\begin{array}{l}\text { Each participant spent } 1 \text { month in } \\
\text { control group with } 2003 \\
\text { requirements allowing " } 24+6 \text { " } \\
\text { hours on duty, and } 1 \text { month in the } \\
\text { intervention group }\end{array}$ \\
\hline Intervention & $\begin{array}{l}\text { Residents limited to shifts of } 16 \\
\text { continuous hours (or } 24 \text { hours } \\
\text { with 5-hour nap); no averaging of } \\
\text { call shifts; maximum of } 4 \\
\text { consecutive nights }\end{array}$ \\
\hline
\end{tabular}

a Flexibility in duty hour requirements for surgical trainees, data from 2014 to 2015 academic year, results from 2015 to 2017 pending. ${ }^{2}$

${ }^{b}$ Individualized comparative effectiveness of models optimizing patient outcome and resident education, enrollment began 2015 , with results pending. ${ }^{9}$

'Neurology prospective duty hour study, 2011. ${ }^{7}$ 
Table 2 Highlighted changes in Section VI of the Common Program Requirements ${ }^{a}$

PGY-1 residents may work 24 continuous hours, allowing 4 additional hours for certain circumstances

Residents may stay beyond the traditional " $24+4$ " hours on their own initiative, for educational or clinical continuity purposes, and return to the hospital with fewer than 8 hours off

Night float may be scheduled for more than 6 consecutive nights (must adhere to 1 day off in 7 , averaged over 4 weeks)

Clinical work performed from home must be counted into the 80 -hour work week maximum (averaged over 4 weeks)

${ }^{a}$ Changes effective July 1, 2017: Clinical Experience and Education Regulations.

patient documentation and after-hours patient and hospital calls, the incorporation of work performed from home into the 80-hour work week will require careful attention to ensure residents do not exceed the 80 -hour maximum. Both positive and negative outcomes resulting from these changes will be monitored by the Review Committee for Neurology through standard ACGME monitoring processes, including the Resident and Faculty Surveys and site visits.

\section{Conclusion}

Clinical experience and education work hour regulations influence resident and fellow education, patient safety, and physician well-being. Prospective studies suggest that shorter continuous work hours lead to a decrease in both educational and clinical outcomes without improvement in patient care. The new requirements in the Common Program Requirements lessen restrictions on work hours, allowing programs flexibility to individualize schedules to best fit program needs. Section VI of the ACGME Common Program Requirements will require continued reassessment to ensure the safety of today's and tomorrow's patients in a supportive clinical learning environment.

More information can be found at www.acgme.org.

\section{Author contributions}

Kathryn Nevel: acquisition of information, drafting and revising the manuscript. Andrew Southerland: drafting and revising the manuscript. Shannon Kilgore: drafting and revising the manuscript. Laurie Gutmann: drafting and revising the manuscript.

\section{Study funding}

No targeted funding reported.

\section{Disclosure}

K. Nevel: Resident member, Accreditation Council of Graduate Medical Education Neurology Review Committee. A. Southerland: Deputy Section Editor, Neurology Podcast. S. Kilgore: Chair, Accreditation Council of Graduate Medical Education Neurology Review Committee. L. Gutmann: Vice Chair, Accreditation Council of Graduate Medical Education Neurology Review Committee; Director, American Board of Psychiatry and Neurology. Go to Neurology.org/ $\mathrm{N}$ for full disclosures.

\section{References}

1. Summary of Changes to the ACGME Common Program Requirements Section VI Available at: acgme.org/What-We-Do/Accreditation/Common-Program-Requirements/ Summary-of-Proposed-Changes-to-ACGME-Common-Program-Requirements-Section-VI. Accessed March 20, 2016

2. ACGME Mission, Vision, and Values. Available at: acgme.org/About-Us/Overview/ Mission-Vision-and-Values. Accessed March 20, 2016.

3. ACGME Common Program Requirements. Available at: acgme.org/What-We-Do/ Accreditation/Common-Program-Requirements. Accessed January 4, 2016.

4. Philibert I, Nasca T, Brigham T, Shapiro J. Duty-hour limits and patient care and resident outcomes: can high-quality studies offer insight into complex relationships? Annu Rev Med 2013;64:467-483.

5. Nasca T, Day S, Amis $S$. The new recommendations on duty hours from the ACGME task force. N Engl J Med 2010;363:e3(1)-e3(6).

6. 2016 Position Statements on Duty Hours and the Learning and Working Environment Available at: acgme.org/What-We-Do/Accreditation/Duty-Hours/2016-Position-Statements-on-Duty-Hours-and-the-Learning-and-Working-Environment. Accessed January 4, 2016.

7. Schuh LA, Khan MA, Harle H, et al. Pilot trial of IOM duty hour recommendations in neurology residency programs: unintended consequences. Neurology 2011;77:883-887.

8. Bilimoria K, Chung J, Hedges L, et al. National cluster-randomized trial of duty-hour flexibility in surgical training. N Engl J Med 2016;374:713-727.

9. Individualized Comparative Effectiveness of Models Optimizing Patient Safety and Resident Education (iCOMPARE). Available at: clinicaltrials.gov/ct2/show/ NCT02274818. Accessed January 6, 2016.

\section{Save These Dates for AAN CME Opportunities!}

Mark these dates on your calendar for exciting continuing education conferences by the American Academy of Neurology. Learn more at AAN.com/conferences.

\section{Breakthroughs in Neurology Conference}

- January 12-15, 2018, Orlando, FL, at the Caribe Royale Orlando 


\section{Neurology}

\section{Residency Training: The Review Committee for Neurology: Revisions to the Common Program Requirements}

Kathryn S. Nevel, Andrew M. Southerland, Shannon M. Kilgore, et al.

Neurology 2018;90;41-44

DOI 10.1212/WNL.0000000000004766

\section{This information is current as of December 28, 2017}

Updated Information \& Services

References

Citations

Permissions \& Licensing

Reprints including high resolution figures, can be found at: http://n.neurology.org/content/90/1/41.full

This article cites 4 articles, 1 of which you can access for free at: http://n.neurology.org/content/90/1/41.full\#ref-list-1

This article has been cited by 2 HighWire-hosted articles: http://n.neurology.org/content/90/1/41.full\#\#otherarticles

Information about reproducing this article in parts (figures,tables) or in its entirety can be found online at:

http://www.neurology.org/about/about_the_journal\#permissions

Information about ordering reprints can be found online:

http://n.neurology.org/subscribers/advertise

Neurology ${ }^{\circledR}$ is the official journal of the American Academy of Neurology. Published continuously since 1951, it is now a weekly with 48 issues per year. Copyright Copyright @ 2017 American Academy of Neurology. All rights reserved. Print ISSN: 0028-3878. Online ISSN: 1526-632X.

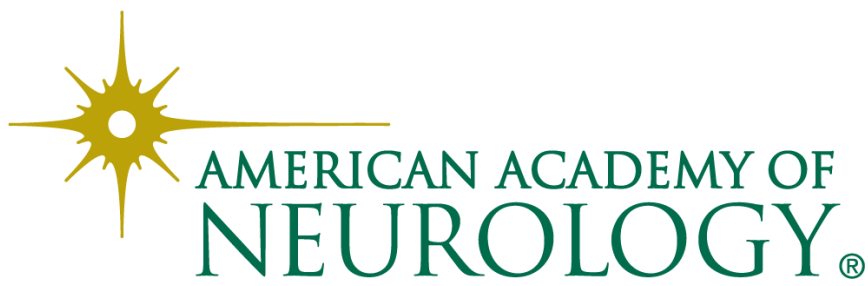

